\title{
Türkçe Öğretiminde Hayal Gücü ve Yaratıcılık Eğitimi $^{1}$
}

\author{
DOI: 10.26466/opus.656984
}

$*$

\begin{abstract}
Dilek Ünveren *
* Dr. Öğretim Üyesi, Süleyman Demirel Üniversitesi, Eğitim Fakültesi, Isparta/Türkiye E-Posta: dilekkapanadze@sdu.edu.tr ORCID: 0000-0003-3415-9274
\end{abstract}

Öz

Yaratıcı bireylerin başat niteliklerinden ve geliştirilebilir özelliklerinden olan hayal gücünün (imgelemci olma) Türkçe öğretimindeki yerinin araştırıldığı bu çalışmada, doküman inceleme yöntemiyle 5. sinıf Türkçe ders kitabı ve öğretim programı incelenmiştir. Böylelikle, kitabın organizasyon şeması içinde yer alan etkinliklerin öğrencilerin yaratıcı düşünme bağlamında hayal kurma yetisine yönelik yeterliliklerini tespit etmek ve şema içindeki hazırlık, dinleme, okuma, konuşma, yazma, sonraki bölüme hazırlık, etkinlik ve tema değerlendirme sorularının hayal kurma yetisine yönelik düzenlenmesi konusunda bir değerlendirmede bulunmak; Türkçe öğretim programının 5. sınıf kazanımlar içinde yaratıcı düşünme bağlamında ele alınan yapılarının hayal gücünü geliştirici olma özelliklerini belirlemek ve bu kazanımların hayal gücü eğitiminde ne şekilde işe koşulacağ konusunda düşünceler ortaya koymak amaçlanmıştır. Sonuç olarak, Türkçe ders kitabında yer alan etkinliklerde öğrencilerin yaratıcılıklarını ve hayal gücünü geliştirecek birçok unsura rastlanmıştır. 5. sınıf Türkçe ders kitabında yer alan etkinlikler; hayal gücü eğitimini sadece formal öğrenme ortamına değil; informal öğrenme koşullarına da taşıyan bir yapıda ele alınmıştır. Türkçe öğretiminde hayal gücü eğitiminin varlığının araştırıldı̆̆ı bu incelemede adı geçen öğrenme alanının bütün temalarda var olduğu görülmektedir. Öğrencilere yaratıcı düşünme becerisi bağlamında hayal gücü kazandırılması hususunda Türkçe öğretim programının beceri alanlarıyla ilgili kazanımlarından bazıları ile hayal gücünü artırıcı çalışmalar yapılabileceği de bu çalışmanın sonucunda ulaşılmışıtır.

Anahtar Kelimeler: Türkçe Öğretimi, Hayal Gücü Eğitimi, Yaratıcılı, Öğretim Programı, Ders Kitabl,

\footnotetext{
${ }^{1}$ Bu araştırma, 25-28 Nisan 2019 tarihlerinde Ankara'da düzenlenen "28. Uluslararası Eğitim Bilimleri Kongresi'nde (ICES/UEBK-2019)" sunulup özet olarak basılmış olan çalışmanın genişletilerek makale haline dönüştürülmesiyle oluşturulmuştur.
} 


\title{
Imagination and Creativity Education in Turkish Teaching
}

\begin{abstract}
In this study, which examines the place of imagination in teaching Turkish, which is one of the important qualities and characteristics of creative individuals, $5^{\text {th }}$ grade Turkish textbook and curriculum have been examined by document analysis method. Thus, it was aimed to identify the competences of the activities within the organizational chart of the book for the improvement of imagination in the context of creative thinking and to make suggestions to develop imaginative thinking; and to identify the characteristics of the imaginary structures of the outcomes in the $5^{\text {th }}$ grade teaching Turkish curriculum and to put forward thoughts about how these outcomes would be employed to develop imagination and creative thinking. As a result, in the activities included in the Turkish textbook, many elements have been found to improve students' creativity and imagination. These activities were found to foster imaginative thinking not only through the formal learning environments but also in informal learning environments. Additionally, these imaginative structures were found in each theme of the book. Moreover, it has been concluded that some of the outcomes related to the areas of skills in teaching Turkish program can be employed in the development of imaginative thinkin.
\end{abstract}

Keywords: Turkish Education, Imagination, Creativity, Curriculum, Textbook, Turkish Teaching, Imagination Education 


\section{Giriş}

Var olan kalıpları yıkma, başkalarının yaşantılarına açık olma, alışılmışların dışına çıkma, bilinmeyenlere doğru bir adım atma, dayatılmış düşünce çizgisini kırma ve yeni bir düşünce çizgisi ortaya koyma, belli bir problem için değişik alternatif çözümler getirme, başkalarının izlediği yoldan çıkma, başka şeylere yol açan yeni bir şey bulma, yeni bir ilişki kurma, yeni bir düşünce ortaya koyma, bilinmeyen yeni bir teknik veya yöntem icat etme ve insanlara yararlı olan bir aracı veya aygitı bulma (Rıza, 2000), ifadelerinden oluşan tanım, yaratıcılık tanımları içinde en geniş perspektifi sunanlardandır.

Davaslıgil (1994) ise yaratıcılığı az kişi tarafından sahip olunan bir yetenek olarak değil, bütün insanların sahip olduğu, geliştirilip sürdürülebilen bilişsel bir beceri şeklinde ifade etmiştir. Yaratıcllı̆ın fark edilmemiş olması durumuna vurgu yapan Aslan (2001)'ın tanımında henüz ürüne dönüşmemiş, kendine özgü bir problem çözme sürecini kapsayan, kişinin zekâ ögelerine dönük bir bilişsel yetenek olduğu belirtilmiştir.

Yaratıcı düşünme bilginin kazanılması için gereklidir, çünkü yaratıcılığın gelişimini sağlayan çevre, aile gibi faktörler bireyin öğrenmeye karşı olumlu tutumlar geliştirmelerine yardımcı olur ve öğrenmeyi güdüler. Yaratıcı düşünme ayrıca sorun çözme, değişimlere uyum sağlama gibi becerileri de kazandırır (Davasligil, 1994).

Yaratıı bireylerin özellikleri ifade edildiğinde başat niteliklerinden birinin de imgelemci (hayal kurucu) olma ifadesine vurgu yapilır. Yine yaratıc1 bireyleri tanıma konusunda ipuçları ifade edilirken 'entelektüel, eğlenceli, düşlem (fantezi) peşinde olup sürekli hayaller kurar' (Üstündağ, 2014) olguları sıralanır ve hayal gücüne de mutlaka değinilir. Yaratıcı bireylerin kişilik özellikleri olarak; öncelikle merak, sabır, buluş ortaya koyma yetisi, imgelemci (hayal kurucu) ve maceracı olma, imgelerle düşünebilme, deney ve araştırmalar yapma konusunda istekli olma, bireşimci (sentezci) yargılara varabilme suralanmaktadır (San, 1985).

Yaratıcılığı etkileyen temel faktörler ise, zekâ, yetenekler, benlik algısı, başa çıkma davranışları ve güdülenme düzeyidir (Doğan, 2015). Bu bağlamda belirli zekâ düzeyine sahip, yetenekli, olumlu benlik algısına sahip, başa çıma davranışları gelişmiş ve yeterince olumlu tutumları olan birey- 
lerde yaratıcı davranışların gözlemlenmesi mümkündür. Bu çerçevede yaratıc bireylerin sahip olduğu ve herkes tarafından kabul gören bazı özellikler şu şekilde sıralanabilir:

- Çok zeki olmalarına gerek yoktur. Orta düzey bir zekâya sahiptirler.

- Kısa sürede yeterli sayıda düşünce üretebilirler.

- Benlik algıları yüksek olmakla beraber olumludur.

- Empatik düşünebilirler.

- Problemi çözme adına istekli ve irade sahibidirler.

- Kesin bilgilere eriştikten sonra karar verirler.

- Bağımsızlıklarına düşkündürler.

- Bir grubun onayına ihtiyaç duymazlar.

- Dogmatik değil, aksine esnektirler.

- Ayrıntılardan çok problemin ana hatları, anlamı ve sonuçlarına odaklanırlar.

- Hayal kurmaktan ve bu hayallerle yaşamaktan hoşlanırlar.

- Başarılıdırlar.

- Meraklidirlar.

- Öz kanitlama içerisindelerdir.

- Şüphecidirler.

- Çok yönlü ilgi alanları vardır.

- Analojik düşünme becerisine sahiptirler (Doğan, 2015).

Bunların dışında da birçok özelliği olan yaratıcı bireylerin ifade edildiği üzere herkesçe kabul gören önemli özelliklerinden biri de hayal kurmaktan ve bu hayallerle yaşamaktan hoşlanmalarıdır.

Hayal kurmanın önünde şüphe yok ki engeller de vardır. Nitekim hayal kurmanın engelleniyor olması demek aynı zamanda bireyin yaratıcı olmasının da engellenmesi anlamına gelir. Bu engellerin de başında uygu bulunmaktadır. Bireyin toplumun birtakım yargılamaları karşısında belli statülere, avantajlı durumlara ya da çıkarlara kavuşabilmek için 'başka' türlü biri olmaya yanaşmaması, zorunlu olmadığı durumlarda ve bir yaptırımla karşılaşmayacağın bilmesine rağmen başka olmayı ve başka davranmayı göze alamayışı, kalıplardan hiç olmazsa belirli ölçülerde kurtulma ya da onları değiştirebilme cesaretini bekleyen yaratıcılığın önünde büyük bir engeldir (San, 1985). 
Yakınsak düşünme de hayal kurabilmenin haliyle yaratıcı olamamanın önündeki en önemli engellerden biridir. Nitekim yakınsak düşünme, alışılmış ve zaten beklenen yanıtlara yönelir. Önceden belli olanı öğrenmeye ve bilinen bu durumu/bilgiyi muhafaza etmeye özgüdür (Samurçay, 1983). Yakınsak düşünme aynı zamanda var olan bilgilerden çıarılan geleneksel sonuçlara götüren düşünme biçimidir. Böyle düşünen bireylerin büyük bir olasllıkla hayal gücüne de gereksinimi yoktur ve yaratıcı üretime de pek az katkıları bulunur (Arık, 1990). Oysa bu düşünce biçimi yerine asıl yaratıcı düşünme biçimi olan ıraksak düşünme ön plana çıkarılmalıdır. Iraksak düşünme cevabı var olan alternatif yollardan elde etmeyi ya da yeni yollar üreterek sorunlara özgün çözümler üretmeyi amaçlar. Iraksak düşünmede insan çeşitli seçenekleri düşünmeye ve onları kullanmaya yönelir, kesin bir doğru yoktur. Seçenekler birey tarafından değerlendirilir ve kişi bireysel bakış açısını ortaya koymaya teşvik edilir (Dolmaz ve Kaya, 2017).

Çağdaş eğitim sistemlerinin yaratıcılığa bakış açısı içerisinde ortaya koyduğu en önemli özelliklerden biri yaratıcılığın geliştirilebilir olmasıdır. Çocukların yaratıcılık serüvenleri okul öncesinden başlar ve okul ortamının çeşitli değişkenleri vasıtasıyla bu özellik ortadan kalkabileceği gibi daha da gelişebilir. Geleneksel öğrenme-öğretme yaklaşımları, öğretmen tutumları gibi yapılar öğrencilerin yaratıc bireyler olmalarının önündeki en çok bilinen engellerdendir. Kırışoğlu'na (1991) göre ise yaratıcılığın önündeki engeller şunlardır:

- Öğrencilerin ilgi, ihtiyaç ve isteklerine uymayan konularda çalışmaya zorlanmamaları.

- Öğrenciye uygun olmayan araç ve gereçlerle çalışılması.

- Öğrenciye detaylı bilgi vermeden çalışılmaya başlanması.

- Öğrencilerin yaratıcılığını geliştirecek kaynakların kullanılmamasi.

- Araç-gereç; bilgi teknolojileri ve çalışma ortamındaki yetersizlikler,

- Sinufların kalabalık olması.

- Mekânın dar ve uygun olmayan bir düzenleme içinde olması,

- Öğretmenlerin öğrencilerine ihtiyaç duydukları zamanı ayırmaması,

- Çevreden yararlanma firsatı verilmemesi. 
Kırışoğlu'nun saydığı bu engeller içinde araç-gereçlerle ilgili engellerin varlığı dikkat çekicidir çünkü ders kitapları öğrenme-öğretme ortamının hem önemli bir aracı hem de ilk akla gelen unsurlarındadır. Bu nedenle ders kitaplarının öğrencilerin hayal dünyalarını zenginleştirici, onların yaratıcı boyutlarını ortaya çıkarıcı nitelikte olması oldukça önemlidir.

\section{Türkçe Öğretimi ve Hayal Gücü Eğitimi}

Düşünme genel olarak insanı diğer canlılardan ayıran en başat akıl fonksiyonu olarak tanımlanmaktadır. Düşünme sadece tek boyuta indirgenemeyen, farklı tanımları yapılan bir kavram olmanın yanında üst düzey olma yönüyle de her bireyde aynı şekil ve düzeyde görülmeyen bir olguyu da ifade etmektedir.

Düşünme ile ilgili birçok tanımın yapılması bu olgunun tek bir şekilde ifade edilemeyeceğini ortaya koymaktadır. Haliyle tek bir düşünmeden ziyade birden çok birden çok düşünme becerisinden bu anlamda söz edilebileceği açk bir durumdur.

Özellikle eğitim psikolojisi alanyazınında düşünme ile ilgili birçok türden bahsetmek mümkündür; yaratıcı, eleştirel, ıraksak, yansıtıcı, metabilişsel bu düşünme türlerinden hemen akla gelenleridir.

2017 yılında uygulamaya konulan Türkçe dersi öğretim programıla Türkçenin eğitimi ve öğretimi alanında daha önce yapılanlara ek olarak yeni ve önemli değişimler meydana getirilmiştir. Öğretim programının Türkçe dersi öğretim programının 'Özel Amaçları' başlığında;

Öğrencilerin hayat boyu kullanabilecekleri dinleme/izleme, konuşma, okuma ve yazma ile ilgili dil becerilerini ve zihinsel becerileri kazanmaları, bu becerileri kullanarak kendilerini bireysel ve sosyal yönden geliştirmeleri, etkili iletişim kurmaları, Türkçe sevgisiyle, istek duyarak okuma ve yazma alışkanlığı edinmelerini sağlayacak şekilde bilgi, beceri ve değerleri içeren bir bütünlük içinde yapılandırılmıştır. Türkçe dersi öğretim programı; dil becerilerinin ve yeterliliklerinin geliştirilmesini, diğer tüm alanlarda öğrenme, kişisel ve sosyal gelişme ile mesleki becerileri edinmenin ön şartı olarak kabul etmektedir. Tematik yaklaşım esas alınarak hazırlanan öğretim programında okuma ve yazma kazanımları metin içi, metin dışı ve metinler arası okuma yoluyla anlam oluşturmayı sağlayacak şekilde yapılandırılmıştır. Birinci sınıftan sekizinci sınıfa kadar kazanımların yapısı ve hiyerarşisi, öğrencilerin 
temel dil becerilerinin yanı sıra üst düzey bilişsel becerilerini geliştirmelerine katkı sağlayacak şekilde düzenlenmiştir (MEB, 2018) ifadelerine yer verilir. Özellikle zihinsel beceriler ve dil becerilerinin yan sıra üst düzey düşünme becerileri vurgusu Türkçe öğretiminin salt ana dili öğretimi olmadığına, aynı zamanda düşünme becerilerinin de merkeze alındığı bir öğretim alanı olduğuna işaret etmektedir.

Türkçe öğretiminde merkeze alınan düşünme becerilerinden en önemlilerinden biri de şüphe yok ki yaratıcı düşünme becerisidir. Yaratmak sözcüğü; zekâ, düşünce ve hayal gücünden faydalanarak önceden var olmayan bir şey üretmek, bir ürün ortaya koymak olarak tanımlanabilirken yaratıcılık ise herkeste bulunduğu kabul edilen, yeni bir şey tasarlama yeteneği olarak ifade edilebilir (TDK, 2011).

Gerek çalışmanın hemen başında yer alan yaratıcı düşünme tanımları gerekse yaratma ve yaratıcılık ifadelerinin referans değerleri düşünüldüğünde bu olgunun temelini özgünlük ve yeni bir ürün ortaya koyma olgularının oluşturduğu görülmektedir. Bunun yolu ise yine yaratıc bireylerde var olduğu bilinen ve yaratıc düşünme becerisinin önemli bir yapı taşını teşkil eden hayal gücünün geliştirilmesinden geçmektedir. Bu anlamda Türkçe öğretim programında yer alan zihinsel beceriler ve dil becerilerinin yanı sıra üst düzey düşünme becerileri ifadeleri yaratıcı düşünme becerisinin haliyle hayal gücü eğitiminin de varlığına işaret etmektedir.

Çocuklar yeni, hızla değişen ve dönüşen dünyalarını anlamlandırmak adına oyun ve hayal gücünü temel mekanizmalar olarak kullanırlar. Başka bir ifadeyle, çocuklar yeni mekânlar, insanlar, nesneler ve fikirlerle karşı karşıya geldikçe oluşan bilgi akışıyla, oyunu ve hayal gücünü kullanırlar başa çıkarlar (Thomas ve Brown, 2016). Bu nedenle çocukların bu özelliklerinin desteklenmesinin ve başta formal öğrenme ortamları olmak üzere, ders araçgereçlerinin çocukların hayal gücünü geliştirecek niteliklere göre düzenlenmesinin önemli olduğu düşünülmektedir.

\section{Amaç}

Bu çalışmanın amacı 5. sınıf Türkçe ders kitabının organizasyon şeması içinde yer alan etkinliklerin öğrencilerin yaratıcı düşünme bağlamında hayal kurma yetisine yönelik yeterliliklerini tespit etmek ve şema içindeki hazırlık, din- 
leme, okuma, konuşma, yazma, sonraki bölüme hazırlık, etkinlik ve tema değerlendirme sorularının hayal kurma yetisine yönelik düzenlenebilmesine ilişkin bir değerlendirmede bulunabilmektir.

Türkçe öğretim programının 5. sınıf kazanımları içinde yaratıcı düşünme bağlamında ele alınan yapılarının hayal gücünü geliştirici olma özelliklerini belirtmek ve bu kazanımların hayal gücü eğitiminde ne şekilde işe koşulacağı konusunda düşünceler ortaya koymaktır.

Ders kitabı içinde yer alan metinlere ek olarak öğrencilerde imgelemci olmanın yolunu açacak metin seçimi önerilerinde bulunmaktır.

Var olan etkinliklerin öğrencilerin hayal gücünü artırıcı şekilde düzenlenmesinin önünü açacak olan örnekler vermek ve yeniden yapılandırılmalarına olanak sağlamaktır.

Öğretmenlerin öğrencilerin hayal gücünü artıracak materyaller tasarlamaları, çağrışımları işe koşabilecekleri ve öğrencilerin hayal gücünü geliştirecek uyaranlarla karşılaşabilecekleri yeni nesil sınıf tasarımları için önerilerde bulunmak

\section{Yöntem}

\section{Araştırmanın Modeli}

Nitel bir çalışma olarak desenlenen bu çalışmada veriler doküman incelemesi yöntemi ile toplanmıştır. İncelenen durumu betimsel olarak açıklayabilmek için nitel araştırma yaklaşımı tercih edilmiştir. Nitel araştırmalarda doğrudan gözlem ve görüşmenin olanaklı olmadığı durumlarda çalışılan araştırma problemiyle ilişkili yazılı ve görsel materyal ve malzemeler de araştırmaya dâhil edilebilir. Doküman incelemesi, araştırılması hedeflenen olgu veya olgular hakkında bilgi içeren yazılı materyallerin analizini kapsar. Dokümanlar, nitel araştırmalarda etkili bir şekilde kullanılması gereken önemli bilgi kaynaklarıdır (Yıldırım ve Şimşek, 2013). Bu bağlamda, 2018-2019 eğitim-öğretim yılı ortaokul 5.sınıflarda okutulan Türkçe ders kitabının organizasyon şeması içinde yer alan etkinlikler taranmıştır. Bu tarama yapılırken şemanın diğer bölümleri olan hazırlık, dinleme, okuma, konuşma, yazma, öğrenelim, sonraki metnin işlenişine hazırlık ve tema değerlendirme sorularına da bakılmış; panoramik bir bakış açısıyla etkinlikler yaratıcı düşünme bağlamında 
hayal gücünü artıracak yapılar ve hayal gücü eğitimi konusunda değerlendirilmiştir. Ayrıca Türkçe dersi öğretim programının 5. sınıf kazanımlarına da bakılmış, hayal gücü eğitimine dair kazanımlar da incelenmiştir.

\section{Veri Toplama Araçları}

Bu araştırmanın veri toplama araçlarını Türkçe öğretim programı ve beşinci sınıf Türkçe ders kitabı oluşturmaktadır.

\section{Verilerin Toplanması ve Çözümlenmesi}

Araştırmada, alanyazından yararlanılarak ve alan uzmanı görüşü alınarak hayal gücü eğitimi bakımından Türkçe öğretim programı ve 5. sınıf Türkçe ders kitabındaki hayal gücü eğitimine dair yapılar belirlenmeye çalışılmıştır.

$\mathrm{Bu}$ çalışmanın verileri; nitel veri analizi yöntemlerinden içerik analizi ile çözümlenmiş ve değerlendirilmiştir. İçerik analizinde temel amaç, toplanan verileri açıklayabilecek kavramlara ve ilişkilere ulaşmaktır. Bu tür analizde veriler derinlemesine bir işleme tabi tutulur ve betimsel bir yaklaşımla fark edilemeyen kavram ve temalar bu analiz sonucu keşfedilebilir (Ylldırım ve Şimşek, 2013). İçerik analizi sözel, yazılı ve diğer materyallerin nesnel ve sistematik bir şekilde incelenmesine olanak tanıyan bilimsel bir yaklaşımdır (Tavşancil ve Aslan, 2001).

Veriler analiz edilirken eş araştırmacılar işe koşulmuştur. Elde edilen veriler iki araştırmacı tarafından bağımsız analiz süreçlerine tabi tutulmuştur. Nitekim nitel veri analizinde deneyimli olan, dışarıdan bir araştırmacıdan faydalanmak çalışmaya katkı sağlayabilir (Yıldırım ve Şimşek, 2013). Araştırmanın güvenirlik hesaplaması için Miles ve Huberman' ın (1994) önerdiği görüş birliği/görüş ayrılığı formülü kullanılmıştır. Araştırmanın güvenirlik çalışması için üç uzmandan, incelenen Türkçe öğretim programında yer alan kazanımlarla 5. sınıf Türkçe ders kitabındaki etkinliklerin hayal gücünü geliştirme bağlamında değerlendirmeleri istenmiştir. Araştırmacı ve alan uzmanlarının görüş birliğine vardıkları unsurlarla güvenirlik sürecinin son bulduğuna karar verilmiştir. Sonraki aşamada yapılan çalı̧̧malar karşılaştırılarak güvenirlik hesaplaması gerçekleştirilmiştir. Hesaplamanın sonunda $\mathrm{p}=$ 0,87 değeri bulunmuştur. Güvenirlik hesaplarının \%70'in üzerinde çıkması, araştırma için güvenilir kabul edilmektedir (Miles ve Huberman, 1994). Buna 
dayanarak elde edilen sonuç, araştırma için güvenilir kabul edilmiştir. Elde edilen bulgular tablolarda doğrudan alıntılanarak verilmiş ve bulguların yorumlanması yoluna gidilmiştir.

\section{Bulgular}

Millî Eğitim Bakanlığ1 5.sınıf Türkçe dersi öğretim programı ve Türkçe ders kitabında hayal gücü ve yaratıcılıkla ilgili yapılan inceleme sonucu elde edilen bulgular bu bölümde ele alınmıştır.

\section{Türkçe Öğretim Programında Hayal Gücü Eğitimi İle İlgili Bulgular}

Eğitim programı içinde en kapsamlı yer tutan bölüm öğretim programı kavramıdır. Herhangi bir dersin öğretimi sürecinde o dersle ilgili bütün yapılacakları kapsayan plandır. Öğretim programı gerek okulda gerekse okul ortamının haricinde öğrenciye kazandırılması için planlamaların yapıldığı bir dersin öğretimi adına oluşan bütün etkinliklerden oluşur (Demirel, 2009). Öğretim programı, eğitim programının ortaya koyduğu amaçlar yönünde bilgi, tutum ve becerilerin kazandırılmasına yönelik olarak hazırlanır (Ünveren Kapanadze, 2018a). Türkçe öğretim programı 5. sınıf kazanımları beceri alanlarında hayal gücü eğitiminde kullanılabilecek yapılar bağlamında incelenmiş elde edilen bulgular Tablo 1'de gösterilmiştir.

Tablo 1. Türkçe Öğretim Programında Hayal Gücü Ĕ̆itimi İle İlgili Bulgular

\begin{tabular}{|c|c|}
\hline K. NU & Kazanımlar \\
\hline & Dinleme \\
\hline \multirow[t]{2}{*}{ T.5.1.7 } & Dinlediklerine/izlediklerine yönelik farklı başlıklar önerir. \\
\hline & Konuşma \\
\hline \multirow[t]{2}{*}{ T.5.2.2 } & Hazırlıksız konuşma yapar. \\
\hline & Okuma \\
\hline T.5.3.15 & Metinde ele alınan sorunlara farklı çözümler üretir. \\
\hline \multirow[t]{2}{*}{ T.5.3.24 } & Okuduğu metnin içeriğine uygun başlık/başlıklar belirler. \\
\hline & Yazma \\
\hline T.5.4.1 & Şiir yazar. \\
\hline T.5.4.2 & Bilgilendirici metin yazar. \\
\hline T.5.4.3 & Hikâye edici metin yazar. \\
\hline T.5.4.14 & Kisa metinler yazar. \\
\hline T.5.4.15 & Yazdıklarının içeriğine uygun başlıklar belirler. \\
\hline
\end{tabular}


Özgün olanı ortaya koyma, yeni bir düşünme şeması içinde bulunma gibi yapıları barındıran yaratıcı düşünme becerisini ortaya koyan bireylerin hayal güçlerini ortaya koyacakları yapılar şüphesiz bir yaratma eylemini ifade eder. Bu özelliği; Şiir yazar, kısa metinler yazar, hikâye edici metinler yazar, hazırlıksız konuşma yapar, başlıklar belirler kazanımlarında görmek mümkündür. Öyle ki yeni bir ürünü ortaya koymak aynı zamanda bir şeyi yeniden var etmektir. Bu aynı zamanda yeni bir düşünceyi ve yeni ürünleri ortaya koyabilme yetisiyle de ilgilidir. Nitekim hayal gücü ve yaratıcılık arasındaki ilişkisel durum düşünüldüğünde söz konusu problemlere karşı özgün çözümler üretme, yeni düşünceler ortaya koyma olguları kendini gösterecektir. Bununla beraber bu kazanımlar hayal gücünün geliştirilmesine yönelik önermeleri de barındırmaktadır. Şöyle ki; yaratıcılığın ve hayal gücünün geliştirilmesinde yeni düşüncelerin oluşturulması, yeni düşünceler ararken keşiflerin yapılması, elde edilmiş düşüncelerin toplanarak ve bir süzgeçten geçirilerek genişletilip özgün kılınması önemli bir yere sahiptir. Tabloda ifade edilen kazanımlar bu bağlam içerisinde değerlendirildiği takdirde hayal gücünün geliştirilmesi çalışmaları içerisinde ele alınabilir.

\section{Türkçe Ders Kitabında Hayal Gücü Eğitimi İle İlgili Bulgular}

Türkçe ders kitapları organizasyon şeması içerisinde şu bölümler bulunmaktadır: Hazırlık, dinleme, okuma, konuşma, yazma, öğrenelim, sonraki metnin işlenişine hazırlık, etkinlik ve tema değerlendirme soruları. Organizasyon şemasının anlatıldığı bölümde etkinlik; bir bilgi ya da beceriyi kazandırmaya ya da geliştirmeye yönelik öğrenciden yapılması istenen çalışma şeklinde tanımlanmaktadır (MEB, 2018). Bu anlamda beşinci sınıf Türkçe ders kitabının etkinlik bölümleri taranmış, Türkçe öğretiminde hayal gücü eğitimi anlamında tespit edilen durumlar betimsel olarak Tablo 2'de gösterilmiştir.

Tablo 2. 5. Sınıf Türkçe Ders Kitabında Hayal Gücü Ĕ̆itimi İle İlgili Bulgular

\begin{tabular}{lll}
\hline Tema & Metin & Etkinlik \\
\hline Çocuk Dünyası & Oyuncak & $\begin{array}{l}\text { Bir oyuncak tasarlasaydınız bu oyuncak nasıl } \\
\text { olurdu? Arkadaşlarınıza anlatınız. }\end{array}$ \\
\hline Çocuk Dünyası & Oyuncak & $\begin{array}{l}\text { Aşağıda verilen boşluğa "oyun ve oyuncak" ko- } \\
\text { nulu bir hikâye yazını. }\end{array}$ \\
\hline
\end{tabular}




\begin{tabular}{|c|c|c|}
\hline Çocuk Dünyası & Çocukluk & $\begin{array}{l}\text { Cahit Sitkı TARANCI 'ya okuduğunuz metnin } \\
\text { içeriğinden hareketle üç soru sorunuz. }\end{array}$ \\
\hline Çocuk Dünyası & Çocukluk & $\begin{array}{l}\text { Aşağıdaki sözcüklerden hareketle bir şiir yazınız. } \\
\text { Şiirinize bir başlık koyunuz. (geçmiş, hayal, öz- } \\
\text { lem, sevmek, çocukluk) }\end{array}$ \\
\hline Çocuk Dünyası & $\begin{array}{l}\text { Ben Bir Çınar } \\
\text { Ağacıydım }\end{array}$ & $\begin{array}{l}\text { Aşağıda giriş bölümü verilen hikâyeyi tamamla- } \\
\text { yınız }\end{array}$ \\
\hline Çocuk Dünyası & $\begin{array}{l}\text { Ben Bir Çınar } \\
\text { Ağacıydım }\end{array}$ & $\begin{array}{l}\text { Siz olsaydınız metindeki çınar ağacını korumak } \\
\text { için neler yapardınız? }\end{array}$ \\
\hline $\begin{array}{l}\text { Millî Mücadele } \\
\text { ve Atatürk }\end{array}$ & Bilmeyen Var Mı? & $\begin{array}{l}\text { Ali, İstiklal Marşı́nı başarılı bir şekilde okuduk- } \\
\text { tan sonra neler yaşanmış olabilir? Hikâyenin de- } \\
\text { vamını yazınız. }\end{array}$ \\
\hline $\begin{array}{l}\text { Millî Mücadele } \\
\text { ve Atatürk }\end{array}$ & $\begin{array}{l}\text { Mustafa Kemal'in } \\
\text { Kağnısı }\end{array}$ & $\begin{array}{l}\text { Elif kağnıyı çekmek için Kocabaş'ın yerine geç- } \\
\text { tikten sonra neler yaşanmış olabilir? Hikâye şek- } \\
\text { linde yazınız. }\end{array}$ \\
\hline $\begin{array}{l}\text { Millî Mücadele } \\
\text { ve Atatürk }\end{array}$ & 15 Temmuz & $\begin{array}{l}\text { Bayrağımız size neler çağrıştırıyor? Çağrışımları- } \\
\text { nızdan hareketle "bağımsızlık" konulu bir ko- } \\
\text { nuşma yapınız. Konuşmanızda kelimeleri an- } \\
\text { lamlarına uygun kullanınız. }\end{array}$ \\
\hline $\begin{array}{l}\text { Millî Mücadele } \\
\text { ve Atatürk }\end{array}$ & 15 Temmuz & $\begin{array}{l}\text { Yukarıda verilen sözlerden hareketle bir şiir ya- } \\
\text { zınız. Şiirinize uygun bir başlık koyunuz. }\end{array}$ \\
\hline $\begin{array}{l}\text { Millî Mücadele } \\
\text { ve Atatürk }\end{array}$ & 15 Temmuz & $\begin{array}{l}\text { Yukarıda verilen sözlerden hareketle bir şiir ya- } \\
\text { zınız. Şiirinize uygun bir başlık koyunuz. }\end{array}$ \\
\hline $\begin{array}{l}\text { Millî Mücadele } \\
\text { ve Atatürk }\end{array}$ & $\begin{array}{l}\text { Dersimiz Atatürk } \\
\text { (Dinleme/İzleme Metni) }\end{array}$ & $\begin{array}{l}\text { Atatürk, } 1923 \text { yılında çağdaş Türkiye'nin kurulu- } \\
\text { şundaki katkıları ile dünyaca ünlü Time (Taym) } \\
\text { dergisinin kapağında yer almıştır. Siz de Time } \\
\text { dergisinin kapağında yer aldığınızı düşünün. Ül- } \\
\text { kenize ve insanlığa yaptığınız hangi hizmetle bu } \\
\text { derginin kapağında yer almak isterdiniz? Kendi } \\
\text { başarınızı anlatan bir yazı yazınız. }\end{array}$ \\
\hline Erdemler & $\begin{array}{l}\text { Karagöz ile Hacivat- } \\
\text { İncelik }\end{array}$ & $\begin{array}{l}\text { Yukarıda, özelliklerini yazdığınız kahramanlar- } \\
\text { dan hangisinin yerine geçmek isterdiniz? Niçin? }\end{array}$ \\
\hline Erdemler & Püf Noktası & $\begin{array}{l}\text { Siz de aşağıda verilen konulardan birini seçerek } \\
\text { seçtiğiniz konu ile ilgili bir hikâye yazınız. } \\
\text { Hikâyenizde daha önce öğrendiğiniz atasözü ve } \\
\text { deyimleri de kullanmaya özen gösteriniz.( sabır, } \\
\text { dürüstlük, sevgi, saygı, dayanışma, iyiliksever- } \\
\text { lik, paylaşma, yardımlaşma...) }\end{array}$ \\
\hline Bilim ve Teknoloji & Uzayda Bir Gün & $\begin{array}{l}\text { Kendinizi Uluslararası Uzay İstasyonu'ndaki ast- } \\
\text { ronotlardan birinin yerine koyunuz. Burada ya- } \\
\text { şadığınız bir olayı hikâye şeklinde kurgulayınız. }\end{array}$ \\
\hline Bilim ve Teknoloji & $\begin{array}{l}\text { Sanki Caminin Bakım } \\
\text { Kılavuzu } \\
\text { (Dinleme/İzleme Metni) }\end{array}$ & $\begin{array}{l}\text { Siz de Mimar Sinan'a cevap olarak bir ileti gön- } \\
\text { dereceğinizi hayal ediniz. } \\
\text { a. İletinizde nelerden bahsederdiniz? Arkadaşla- } \\
\text { rınızla tartışınız. Öğretmeninizin yönlendirmesi } \\
\text { ile beyin fırtınası yapınız. } \\
\text { b. İletinizi aşağıya e-posta şeklinde yazınız. }\end{array}$ \\
\hline
\end{tabular}




\begin{tabular}{|c|c|c|}
\hline Millî Kültürümüz & Anadolu Sevgisi & $\begin{array}{l}\text { "Anadolu, sevgi, dağlar, yayla, ova, deniz, köy ve } \\
\text { halk" kelimelerinden en az üçünü kullanarak bir } \\
\text { şiir yazınız. Şiirinize uygun bir başlık koyunuz. }\end{array}$ \\
\hline Millî Kültürümüzz & Anadolu Sevgisi & $\begin{array}{l}\text { a. Türkiye'nin tanıtımıyla ilgili videoyu izleyiniz. } \\
\text { Kendinizi,Türkiye'yi yurt dışında tanıtan biri ola- } \\
\text { rak hayal ediniz ve aşağıdaki soruları cevaplayı- } \\
\text { nız. } \\
\text { b. Türkiye'nin tanıtımında görevli biri olarak ül- } \\
\text { kemizin bu yılki tanıtım afişini düzenliyorsunuz. } \\
\text { İzlediklerinizden ve hayal gücünüzden hareketle } \\
\text { defterinize ülkemizin tanıtım afişini çiziniz. }\end{array}$ \\
\hline Millî Kültürümüzz & $\begin{array}{l}\text { Tamburi Cemil Bey } \\
\text { Enstrümanları Tanitiyor }\end{array}$ & $\begin{array}{l}\text { Yandaki bölüme seçtiğiniz bir enstrümanla ilgili } \\
\text { karikatür çiziniz. Karikatürünüzün mesajını içe- } \\
\text { ren bir slogan yazınız. }\end{array}$ \\
\hline Millî Kültürümüzz & $\begin{array}{l}\text { Dede Korkut-Boğaç Han } \\
\text { (Dinleme/İzleme Metni) }\end{array}$ & $\begin{array}{l}\text { Aşağıdaki bilgilerden ve sorulardan hareketle } \\
\text { konuşmanızı yapınız. } \\
\text { Çizgi filmde çocuklar yaptıkları kahramanlığa } \\
\text { göre isim almaktadır. O dönemde yaşadığınızı } \\
\text { hayal ediniz. } \\
\text { 1. İsim almak için nasıl bir kahramanlık yapardı- } \\
\text { nız? } \\
\text { 2. Bu kahramanlık sonucunda hangi ismi almak } \\
\text { isterdiniz? }\end{array}$ \\
\hline Millî Kültürümüzz & $\begin{array}{l}\text { Dede Korkut-Boğaç Han } \\
\text { (Dinleme/İzleme Metni) }\end{array}$ & $\begin{array}{l}\text { Dede Korkut, Dirse Han'ın oğluna isim verdik- } \\
\text { ten sonra olaylar nasıl gelişmiş olabilir? Olayların } \\
\text { gelişimine uygun bir son yazınız. }\end{array}$ \\
\hline Millî Külttürümüz & Forsa & $\begin{array}{l}\text { Kara Memiş, oğlu Turgut Bey ile beraber cenk et- } \\
\text { tikten sonra deniz yoluyla Malta Adası'ndan } \\
\text { memleketi Edremit' e dönecektir. Kendinizi met- } \\
\text { nin kahramanı Kara Memiş' in yerine koyunuz. } \\
\text { Aşağıdaki haritaya, memlekete dönebileceğiniz } \\
\text { rotayı çiziniz. Daha sonra aşağıdaki bilgilerden, } \\
\text { sorulardan ve hayal gücünüzden hareketle ko- } \\
\text { nuyla ilgili bir konuşma planlayınız. }\end{array}$ \\
\hline Okuma Kültürü & Kitabın Serüveni & $\begin{array}{l}\text { Kendinizi şiirdeki kavak ağacının yerine koyarak } \\
\text { duygu ve düşüncelerinizi anlatan bir şiir yazınız. } \\
\text { Şiirinize uygun bir başlık belirleyiniz. }\end{array}$ \\
\hline Okuma Kültürü & Keramet Kavukta Mi? & $\begin{array}{l}\text { Siz de kitap okurken kitap kahramanlarıyla ken- } \\
\text { dinizi özdeşleştirir misiniz? Onlarla dostluk ku- } \\
\text { rar mısınız? Açklayınız. }\end{array}$ \\
\hline Okuma Kültürü & Okuma Kitaplarım & $\begin{array}{l}\text { "Okuma Kitaplarım" metninden ve aşağıdaki } \\
\text { görsellerden hareketle yazarın okuma kitapla- } \\
\text { rında neler bulunduğunu yorumlayınız. }\end{array}$ \\
\hline Okuma Kültürü & Karikatür & $\begin{array}{l}\text { Siz olsaydınız bu mesajı nasıl karikatürize eder- } \\
\text { diniz? Yandaki bölüme kendi çiziminizi yapınız. } \\
\text { Aşağıda verilen karikatürlerin konusundan ha- } \\
\text { reketle uygun sözler yazarak kahramanları ko- } \\
\text { nuşturunuz }\end{array}$ \\
\hline
\end{tabular}




\begin{tabular}{|c|c|c|}
\hline Okuma Kültürü & $\begin{array}{l}\text { Küçük Şeylerin } \\
\text { Hikâyesi-Kütüphane } \\
\text { (Dinleme/İzleme Metni) }\end{array}$ & $\begin{array}{l}\text { Aşağıdaki afiş size neler çağrıştırmaktadır? } \\
\text { Afişle ilgili duygu, düşünce ve hayallerinizi anla- } \\
\text { tan bir yazı yazınız. }\end{array}$ \\
\hline Doğa ve Evren & $\begin{array}{l}\text { Yüksek Evde } \\
\text { Oturanın Türküsü }\end{array}$ & $\begin{array}{l}\text { Okuduğunuz şiirin ana duygusunu göz önünde } \\
\text { bulundurarak ve görsellerden faydalanarak siz } \\
\text { de bir şiir yazınız. }\end{array}$ \\
\hline Doğa ve Evren & Reçete & $\begin{array}{l}\text { Aşağıda serim (giriş) bölümü verilen hikâyeyi ta- } \\
\text { mamlayınız. Hikâyenize uygun bir başlık koy- } \\
\text { mayı unutmayınız. }\end{array}$ \\
\hline Sağlık ve Spor & $\begin{array}{l}\text { Anadolu'nun Cirit } \\
\text { Oyunları }\end{array}$ & $\begin{array}{l}\text { Festival alanında eksik olduğunu düşündüğü- } \\
\text { nüz bir bölüm var mı? Alana hangi bölümü ekle- } \\
\text { mek isterdiniz? Niçin? }\end{array}$ \\
\hline Sağlık ve Spor & Sağlıklı Yaşıyorum & $\begin{array}{l}\text { Mete GAZOZ, } 17 \text { yaşındayken ülkemiz adına } \\
2016 \text { Rio Olimpiyat Oyunları'na katıldı. Genç ya- } \\
\text { şına rağmen okçuluk müsabakalarında göster- } \\
\text { diği başarıyla dikkat çekti. Siz, ülkemizi olimpi- } \\
\text { yat oyunlarında temsil edecek olsanız hangi } \\
\text { alanda yarışmak isterdiniz, niçin? }\end{array}$ \\
\hline
\end{tabular}

Yaratıcı davranışlara ilham kaynağı olabilecek birçok değişkenden söz edilebilir. İham ya da esin şüphesiz yaratıcı sürecin çok önemli bir parçasını teşkil etmektedir. Esini harekete geçiren etmenler olarak; çevre, farklı sesler, bir kişinin gülüşü ya da başka bir duygu ifadesi, görüntüler, düşler, sevmek, âşık olmak, reddedilmek, hayal kırıklıkları, tesadüfler, kazalar vb. durumlar sıralanabilir (Wilson, 1997-Akt: Üstündağ, 2014). Bu anlamda öğrencilerin yaratıclıklarını ortaya koyacak ve esin kaynağı olabilecek işlevsel araçları işe koşmanın, bu becerinin, haliyle hayal gücünün geliştirilmesinde yadsınamaz öneminin olduğu açıtır. Öğrenme-öğretme ortamının önemli araç gereçlerinden olan ders kitapları da bu bağlam içerisinde değerlendirilmelidir. Ders kitabı öğrencilerin konulara ait bilgileri belli bir sırada ve amacına uygun şekilde öğrenmeleri adına dersin öğretim programında ifade edilen amaçlar doğrultusunda hazırlanmış olan yazılı materyallerdir. Öğrencinin öğrenme ile ilgili deneyimlerinde sadece okulda değil; okul dışında da eşlik etmesi, öğretmenin öğretim ortamında gücünü daha iyi kullanması ve sistematik bilgiler sunmasına imkân veren araçlar olması nedeniyle doğru bir şekilde yapılandırılması ve dersin öğretimi, kazandırılmak istenen hedef davranışlar ile ilişkili bir biçimde, onun belirlediği ölçütler doğrultusunda hazırlanması gereken bir eğitsel ortamı ifade ederler (Ünveren Kapanadze, 2018b). 
Bu bakış açısının hâkim kılındığı bu araştırmada Türkçe ders kitabında yer alan etkinliklerde öğrencilerin yaratıcılıklarını ve hayal gücünü geliştirecek birçok unsura rastlanmıştır. 5. sınıf Türkçe ders kitabında yer alan etkinlikler; hayal gücü eğitimini sadece formal öğrenme ortamına değil; informal öğrenme koşullarına da taşıyan bir yapıda ele alınmıştır.

5.sınıf Türkçe ders kitabı; Çocuk Dünyası, Millî Mücadele ve Atatürk, Erdemler, Bilim ve Teknoloji, Millî Kültürümüz, Okuma Kültürü, Doğa ve Evren, Sağllk ve Spor adlı temalardan oluşmaktadır. Türkçe öğretiminde hayal gücü eğitiminin varlığının araştırıldığı bu incelemede adı geçen öğrenme alanının bütün temalarda var olduğu görülmektedir.

Türkçe ders kitabı şeması içerisinde önemli bir ölçüde yer alan, sadece ilgili metin bağlamında değil; başka metinlerle de desteklenerek oluşturulmuş olan etkinlikler bölümü hayal gücünü geliştirecek yapı taşlarından oluşmaktadır. Her ne kadar her temada eşit ölçüde dağılım göstermemiş olsa dahi hayal gücü eğitimine ait birçok etkinliğin ders kitabı etkinliklerinde olduğu çalışmanın bulgularındandır.

Türkçe öğretiminin temel beceri alanları olan dinleme, konuşma, yazma ve okuma ile ilgili olarak oluşturulmuş olan etkinliklerde bu anlama-anlatma becerilerinin her birine ait hayal gücü eğitimi bağlamında kullanılabilecek, doğrudan hayal gücü ve yaratıcılığa hizmet edecek yapılar olduğu yine bu araştırmanın önemli bulgularındadır. Bir oyuncak tasarlasaydınız bu oyuncak nasıl olurdu? Arkadaşlarmıza anlatını etkinliği konuşma, Aşağıdaki sözcüklerden hareketle bir şïr yazınız. Şiirinize bir başlık koyunuz (geçmiş, hayal, özlem, sevmek, çocukluk) etkinliği yazma beceri alanı ile bütünleştirilmiş bir hayal gücü etkinliğine örnek olarak gösterilebilir.

Etkinliklerin bir bölümünün ders ortamında yapılması planlanmışken bazı etkinlikler okul dışında başka öğrenme ortamlarına göre de düzenlenmiştir. Etkinlik cümlesi her ne kadar sınıf ortamında yapılması şeklinde düzenlenmiş olsa da söz konusu etkinliğin bir süreci ifade etmesi, sinıf ortamında hemen yapılamayacağı göz önünde bulundurulduğundan bazı etkinliklerin hayal gücünün geliştirilmesi açısından ders ve okul dışı öğrenme ortamlarına gereksinim duyduğu ifade edilebilir ve aşağıdaki etkinlikler bu duruma örnek gösterilebilir: 
a) Türkiye'nin tanttımıla ilgili videoyu izleyiniz. Kendinizi, Türkiye'yi yurt dışında tanıtan biri olarak hayal ediniz ve aşă̆ıdaki soruları cevaplayiniz.

b) Türkiye'nin tanıtımında görevli biri olarak ülkemizin bu yılki tanıtım afişini düzenliyorsunuz. İzlediklerinizden ve hayal gücünüzden hareketle defterinize ülkemizin tanıtım afişini çiziniz.

Öğrencilerde hayal gücünü geliştirecek olan etkinliklerde daha çok, onların yaratıcı ve sentezleyici özelliklerinin ortaya çıkarılması bağlamında bir yapılandırma söz konusudur:

- Yukarıda verilen sözlerden hareketle bir şiir yazını. Şiirinize uygun bir başlık koyunuz.

- Ali, İstiklal Marşı'nı başarılı bir şekilde okuduktan sonra neler yaşanmış olabilir? Hikâyenin devamın yazınız.

- Aşağıda serim (giriş) bölümü verilen hikâyeyi tamamlayını. Hikâyenize uygun bir başlık koymayı unutmayını.

Yukarıdaki etkinliklerde olduğu gibi hayal gücü ve yaratıcılık alanları; bir bölümü verilmiş olan herhangi bir metnin öğrencilerin hayal gücünü ortaya koyarak tamamlamaları ya da baştan sona bütün bir metin oluşturmaları yönüyle yapılandırıldığı görülmüştür.

Hayal gücü eğitiminde görsellerin ve göstergelerin çok önemli bir yeri vardır. Nitekim Açıkalın (2002), yaratıcılığın biyolojik temelleriyle ilgili yaptığı çözümlemede beynin farklı bölgelerinin farklı işlevleri yerine getirdiği yönündeki bulgulara rağmen, yine de beynin işleyişinde bir bütünlüğün olduğunu ifade etmektedir. Yaratıcı bireylerin sentezleme becerileri içerisinde analojik düşünebilme, zihinde canlandırma -hayal etme- gibi özellikleri düşünüldügünde bu bütünlük görsellerin ve göstergelerin bireyin hayal dünyası için önemini bir kere daha ortaya koymaktadır. Bu bağlamda, aşağıdaki etkinlikler, görsellerin ve göstergelerin hayal gücü eğitiminde kullanımına dair yapılar olarak araştırmanın bulgularına yansımıştır:

- Bayrağımız size neler çağrıştırıyor? Çă̆rışımlarınızdan hareketle "bağımsızlık" konulu bir konuşma yapını. Konuşmanızda kelimeleri anlamlarma uygun kullaniniz. 
- Atatürk, 1923 yılında çağdaş Türkiyénin kuruluşundaki katkıları ile dünyaca ünlü Time dergisinin kapağında yer almıştır. Siz de Time dergisinin kapă̆̆ıda yer aldığınızı düşünün. Ülkenize ve insanlı̆̆a yaptığınız hangi hizmetle bu derginin kapağında yer almak isterdiniz? Kendi başarinızı anlatan bir yazı yazını.

- Türkiye'nin tanttımiyla ilgili videoyu izleyiniz. Kendinizi, Türkiye'yi yurt dışında tanıtan biri olarak hayal ediniz ve aşağıdaki soruları cevaplayıniz

- Siz olsaydını bu mesajı nasıl karikatürize ederdiniz? Yandaki bölüme kendi çiziminizi yapınız.

- Aş̧ă̆ıdaki afişsize neler çağrıştırmaktadır? Afişle ilgili duygu, düşünce ve hayallerinizi anlatan bir yazı yazını.

Tablo 2'de gösterilen etkinlikler; doğrudan hayal gücü eğitiminde kullanılabilecek, hayal gücünün geliştirilmesi için işe koşulabilecek ve yaratıcıllğ ortaya kayabilecek yapıları ifade etmektedir. Bazı etkinliklerde hayal gücü ifadesi doğrudan da yer almaktadır. Bunlar:

- Siz de Mimar Sinan'a cevap olarak bir ileti göndereceğinizi hayal ediniz. a) İletinizde nelerden bahsederdiniz? Arkadaşlarınızla tartışını. Öğretmeninizin yönlendirmesi ile beyin firtınası yapını. b) İletinizi aşağ̊ya eposta şeklinde yazını.

- Aşă̆ıda verilen karikatürlerin konusundan hareketle uygun sözler yazarak kahramanları konuşturunuz b) Türkiye'nin tanıtımında görevli biri olarak ülkemizin bu yılki tanıtım afişini düzenliyorsunuz. İzlediklerinizden ve hayal gücünüzden hareketle defterinize ülkemizin tanıtım afişini çiziniz.

- Aşă̆ıdaki bilgilerden ve sorulardan hareketle konuşmanızı yapınız. Çizgi filmde çocuklar yaptıkları kahramanlı̆̆a göre isim almaktadır. O dönemde yaşadığınızı hayal ediniz. 1. İsim almak için nasıl bir kahramanlık yapardiniz? 2. Bu kahramanlik sonucunda hangi ismi almak isterdiniz?

- Aşă̆ıdaki afişsize neler çağrıştırmaktadır? Afişle ilgili duygu, düşünce ve hayallerinizi anlatan bir yazı yazını.

Yaratıcılığın önemli öğelerinden biri de şüphe yok ki iletişim becerileridir. İletişim becerisi kişinin duygu ve düşüncelerini başkalarına 
sözlü, yazılı, görüntülü vb. yollarla açı, net, doğru ve uygun bir şekilde ifade etme olarak tanımlanabilir. Dil hâkimiyeti ve zengin bir sözcük dağarcığına sahip bulunan kişilerde yaratıcılığın görünüşü, sözcükler arasında kurulmuş olan özel bir ilişkiyi açıklar (Rıza, 2001). İletişim becerileri sadece burada ifade edilenlerle değil; yaratıcı bireylerde özellikle hayal kurma anlamında empatik bir duyuş ve düşünüş tarzını da ifade eder. Empati, kişiler arası iletişimin önemli bir ayağını ifade eder. En genel tanımıyla empati; bir kişinin kendini başkasının yerine koyarak olaylara, durumlara onun bakış açısıyla bakarak yaklaşması, o kişinin duygularını ve düşüncelerini doğru olarak anlaması ve hissetmesi sürecidir (Akkoyun, 1983). Etkinliklerden bazıları yaratıcılık ve hayal gücü bağlamında yapılandırılırken empatik düşünme becerisiyle ilişkilendirilmiştir. Kendisini bir başkasının yerine koyarak hayal gücünün işe koşulması istenmiştir. Aşağıdaki etkinlikleri bunlardan birkaçına örnektir:

- Siz olsaydınız metindeki çınar ağacını korumak için neler yapardınız?

- Kendinizi Uluslararası Uzay İstasyonu'ndaki astronotlardan birinin yerine koyunuz. Burada yaşadığını bir olayı hikâye şeklinde kurgulayınız.

- Kendinizi şiirdeki kavak ağacının yerine koyarak duygu ve düşüncelerinizi anlatan bir şiir yazını. Şiirinize uygun bir başlık belirleyiniz.

Sonuç olarak, 5. sınıf Türkçe ders kitabı etkinlikleri öğrencilerin yaratıc1lıklarını destekleyen, onlara hayal kurmanın kapılarını açan, öğretmenlere öğrencilerin hayal dünyasını zenginleştirebileceği ve hayal gücü eğitimi verebileceği zengin imkânlar sunmaktadır. Gerek öğretim programı gerekse ders kitabı etkinlikleri bağlamında araştırma bulguları hayal gücü eğitiminin etkinliklerle etkili bir şekilde yapılabileceğini göstermektedir.

\section{Sonuç}

Yeni ve çağdaş öğrenme kültür ve yaklaşımlarında öğrenmelerin büyük bölümünün geleneksel eğitim ortamının dışında meydana geliyor olmasına karşın sınıf içi öğrenmelerin de yeri ve önemi yadsınamaz düzeydedir. Yeni nesil öğrenme kültüründe devamlı öğrenme, bilgiyi yapılandırma ve keşfetme duygusunu harekete geçiren yapı taşları önem kazanmıştır. Haliyle 
hem sınıf içi hem de sınıf dışındaki öğrenme ortamlarının elde edilen bu bilginin yapılandırılması ve anlamlandırılması sürecine olanak sağlayan unsurlardan oluşturulması bir anlamda eğitim-öğretim faaliyetlerinin sürekliliği ve kalıclığı için yaşamsal önem arz etmektedir. Şüphesiz bunu tesis edecek en önemli unsurlardan biri de öğrencilerin bilgiyi anlamlı kılmasına olanak sağlayacak düşünme becerileriyle donatılmış olmasıdır. Bu düşünme becerilerinden biri de yaratıcı düşünme ve bu düşünme tarzının önemli bir ayağını oluşturan hayal gücüdür.

Guilford (Akt. Doğan, 2015), zekâ kavramına açıklama getirdiği kuramında yaratıcilığı ifade ederken onu, zekânın bir boyutu olarak özgün, akıcl, esnek ve alışılmış kalıpların dışında olarak ifade etmektedir. Nitekim çeşitli kaynaklarda yaratıcilık; ana yollardan ayrılma, kalıpların dışına çıkma, çok çağrışımlı düşünebilme, çağrışımlar üretmede alabildiğine özgür olma ve bunu ortaya koyarken problemin özünden ayrılmama, başka hiç kimsenin göremediğini görme ve sezme, bilişsel, duyuşsal ve devinişsel davranışların tamamında yeni bir davranışı ortaya koyma şeklinde tanımlanmaktadır (Dikici, 2001; Oğuzkan vd., 1999; Ülgen, 1997; Üstündağ, 2014). Millı̂ Eğitim Bakanlığı programında eğitim yoluyla topluma kazandırılmak istenen birey ile ilgili şu ifadelere yer verilmektedir:

Bilim ve teknolojide yaşanan hızlı değişim, bireyin ve toplumun değişen ihtiyaçları, öğrenme öğretme teori ve yaklaşımlarındaki yenilik ve gelişmeler bireylerden beklenen rolleri de doğrudan etkilemiştir. Bu değişim bilgiyi üreten, hayatta işlevsel olarak kullanabilen, problem çözebilen, eleştirel düşünen, girişimci, kararll, iletişim becerilerine sahip, empati yapabilen, topluma ve kültüre katkı sağlayan vb. niteliklerdeki bir bireyi tanımlamaktadır (MEB, 2018).

Böylesi bir birey/öğrenci profiline ulaşabilmeni yolu da üst düzey düşünme becerilerine sahip olmakla birlikte bu becerileri yaşamının her aşamasında kullanabilen insanlar yetiştirmekten geçmektedir. Bu anlamda bir üst düzey düşünme becerisi olan yaratıcı düşünmeyi merkeze alarak yapılan çalışmalar bulunmaktadır. Türkçe Öğretiminde Yaratıı Düşünmeyi Geliştirme Bakımından Nasreddin Hoca Fıkraları (Temizkan, 2011), Türkçe Öğretiminde Yaratıcı Yazma Becerisini Geliştirme ve Küçürek Öykü (Demir, 2012) gibi çalışmaların yanında yaratıcılık bağlamlı tür, yöntem ve teknikler ile tutumlar konusunda da yapılan araştırmalar bulunmaktadır. Ancak yaratıcı 
düşünmenin temel unsurlarından hayal gücü unsuru bu anlamda ihmal edilmiş, yalnızca yaratıcılık ve yaratıcı düşünmenin ana hatları bağlamında çalışmalar yapıldığı görülmüştür. Yapılan bu çalışmada yaratıcı düşünme temelinde Türkçe öğretiminde hayal gücü eğitimi araştırılmış, elde edilen bulgular ışı̆̆ında şu sonuçlara ulaşılmıştır.

Öğrencilere yaratıcı düşünme becerisi bağlamında hayal gücü kazandırılması hususunda Türkçe öğretim programını beceri alanlarıyla ilgili kazanımlarından bazıları ile hayal gücünü artırıcı çalışmalar yapılabileceği bu çalışmanın sonucunda ulaşılmıştır. İncelemesi yapılan Türkçe ders kitabı organizasyon şeması içeriği içindeki etkinliklerden bazılarının da bu amaca yönelik olduğu görülmüştür. Bununla beraber kitabın maliyet ve basım koşulları ile ilgili olarak hayal gücünü destekleyecek uyaranların eksikliği de yine bu çalışmada tespit edilmiştir. Etkinliklerle ilişkili olan hazırlık, dinleme, okuma, konuşma, yazma, sonraki bölüme hazırlık ve tema değerlendirme sorularından bazılarının da hayal gücü eğitimine ve bu becerinin edindirilmesine katkı sağlayacak düzeyde olduğu yine çalışmanın sonucuna yansımıştır.

Öğrencilerin imgelemci yönünün geliştirmesi için sadece Türkçe dersi için MEB tarafından üretilmiş olan materyaller işe koşulmamalı ve bunlarla yetinilmemelidir. Bu konuda öğretmen ve öğrencilerin ihtiyacını karşılayabilecek doküman ve metin Türk ve Dünya çocuk edebiyatında yer almaktadır. Çocukların bilişsel gelişim süreçleri göz önünde bulundurulmak kaydıyla Türk halk edebiyatının fantastik türlerinden masal, destan, efsane gibi türlerin yanında fabl gibi masalımsı türlerden de amaca hizmet edeceği düşünülen metinlerin sınıf ortamına getirilmesi ya da sınıf dışında öğrencilere sunulmasının önemi de bu çalışma sonucunda ortaya çıkmıştır. Zira masal ve bu türden kurgusal türler, başka bir deyişle masal dünyası çocuğun gerçek dünyasıdır. Masalların bütün dekoruna çocuğun benlik duygusu, animist ve simgeci ruhu sinmiştir. Masalların yanı sıra, öykü/roman gibi yapılardan da daha fazla yararlanılması gerektiği sonucuna ulaşılmıştır. Kısıtlı yaşam deneyimi olan çocuklar bu türler vasıtasıyla düşsel arkadaşlar edinebilir, yeni dünyaları ve duyuşları tanıyabilir. Bütün bunlar yapılırken salt okuma ve metni anlamlandırma ile yetinilmemeli hayal gücünü artıracak sesleme, görsel gibi uyaranlarla da sinıf/okul iklimi zenginleştirilmelidir.

Kavramsal anlama ve becerilerin ön plana çıarıldığı yapılandırmacı yaklaşımda öğretmen içeriği sunan değil; öğrenme çabalarını destekleyen bir ko- 
numdadır. Program, haliyle öğrenenlerin okulda ve okul dışında yararlı bulacağı bilgi ve becerilere göre tasarlanmaktadır. Bu anlamda öğrencilerde hayal gücünü artıracak etkinlikler hazırlayıp yeni deneyimler kazandıracak olanaklar sunmak önem kazanmaktadır. Türkçe öğretimi bir beceri kazandırma sürecini ifade eder. Beceriler de uygulamalarla geliştirilebilir. Yaratıcılık bağlamında hayal gücünün geliştirilmesi ya da var olan bu gücün daha ileri noktalara taşınmasında uygulamaya dayanmayan bir öğretimin istenen seviyede bir beceri kazandırması beklenemez. Bu nedenle yaratıcılık bağlamında öğrencilerin hayal güçlerinin geliştirilmesinde yapılabilecek ve Türkçe ders kitaplarında yer verilmesinin önemli olduğu kanısına varılan bazı etkinlikler şunlardır:

- Öykü resimleme

- Şiir resimleme

- Herhangi bir öykü ya da başka anlatısal türü oyunlaştırma

- Çağrışımları yazma

- Kendini bir başka canlı ya da nesnenin yerine koyma

- Düşleneni yazma

- Geleceğe gitme

Bunlarla beraber yaratıcılığın geliştirilmesinde kullanılan beyin firtınası, yaratıcı problem çözme, görüş geliştirme, kavram haritaları, altı şapka düşünme tekniği gibi tür, yöntem ve tekniklerden de yararlanılması gerektiği sonucuna ulaşılmıştır.

\section{Öneriler}

Türkçe dersinde öğrencilerin hayal gücünün geliştirilmesi için öneriler şunlardır:

- Çok yönlü düşünebilmekle söz varlığı arasında doğrusal bir durumun olduğu açıtır. Bu nedenle öğrencilerin söz varlığının geliştirilmesine yönelik çalışmalara hem öğretim programında hem de Türkçe ders kitabında daha fazla yer verilmesi önerilmektedir.

- Hayal gücünün geliştirilmesinde uyaranların önemli rol oynadığı açıktır. Bu bağlamda birey etrafında ne kadar çok uyaranla karşı karşıya gelirse 
sinir sistemi de o denli gelişeceğinden, önceki uyaranlarla ilişki kurarak bilgi deposu zenginleşir. Bu bağlamda, Türkçe ders kitabındaki yönergelerin çoklu uyaran teşviki bağlamında güçlendirilmesi önerilmektedir.

- Türkçe derslerinde, ders kitabı ve programda hayal gücü ile ilgili bu çalı̧̧mada ortaya çlkan unsurları destekleyecek şekilde, yeni düşüncelerin oluşmasına zemin hazırlayacak ortamların ve hayal gücünü artırıc bir atmosferin öğretmenler tarafından oluşturulmasının önemli olduğu düşünülmekte ve bu yönde öğretmenlerin desteklenmesi önerilmektedir.

- Türkçe dersleri başta olmak üzere tüm dersler/sınıflar adeta bir hayal kurma atölyesi/laboratuvarı şeklinde düzenlenmelidir. Türkçe ders kitaplarına ek olarak ve onları destekleyici şekilde EBA üzerinden öğrencilere doğrudan yaşantı yoluyla olmasa bile düşsel birtakım yaşantılar gerçekleştirmelerinin yolunun açılması yönüne adımlar atılması önerilmektedir. 


\title{
EXTENDED ABSTRACT
}

\section{Imagination and Creativity Education in Turkish Teaching}

\author{
* \\ Dilek Ünveren \\ Süleyman Demirel University
}

The structure and hierarchy of the objectives of Ministry of National Education Turkish teaching program from the first grade to the eighth grade are arranged to contribute to the development of students' basic language skills as well as their high level cognitive skills. The emphasis on higher-order thinking skills as well as language skills indicates that Turkish teaching is not only a mother tongue teaching, but also a teaching area where thinking skills are also centered.

One of the most important thinking skills centered in Turkish teaching is undoubtedly creative thinking skills. Creativity can be defined as the ability to design something new by making use of intelligence, thought and imagination, to design or produce something that does not exist before. Therefore, the origin of this phenomenon is originality and the emergence of a new product. The way to this is through the development of imagination, which is also known to exist in creative individuals and constitutes an important building block of creative thinking skills. In this sense, in addition to the cognitive skills and language skills included in the Turkish teaching curriculum, statements of high-level thinking skills indicate the existence of imagination education as well as the creative thinking skill.

In this study, which was designed as a qualitative study, data was collected by document analysis method. In this context, the activities included in the organizational chart of the Turkish textbook that was taught in the 5th grades of 2018-2019 academic year were examined. While doing this review; preparation, listening, reading, speaking, writing, learning, preparation of the next text, and theme evaluation questions were examined. With a panoramic perspective, activities were evaluated about the structures that will increase imagination education in the context of creative thinking. In addition, the $5^{\text {th }}$ grade objectives of the Turkish curriculum were also examined in the context 
of imagination education. The data of this study were analyzed and evaluated by content analysis method. While analyzing the data, co-researchers were employed. The data obtained were subjected to independent analysis processes by two researchers.

Structures through which individuals who demonstrate their creative thinking skills, such as revealing an original and new way of thinking scheme, will undoubtedly represent an act of creation. It is possible to see these features in the objectves of $5^{\text {th }}$ grade Turkish teaching curriculum as; 's/he writes poets, writes short texts, writes narrative texts, makes unprepared speeches, identifies titles for the texts'.

Additionally, many elements that would improve the creativity and imagination of the students were found in the activities of the Turkish textbook. Activities in the $5^{\text {th }}$ grade Turkish textbook were structured as to transfer imagination education not only to formal learning environment; but also to informal learning opportunities.

$5^{\text {th }}$ grade Turkish textbook consists of the themes of; "The World of Children, National Struggle and Atatürk, Virtues, Science and Technology, Our National Culture, Reading Culture, Nature and Universe, Health and Sports'. In this study, where the existence of imagination education was investigated in Turkish teaching, it was seen that the learning area mentioned exists in all of the themes of the curriculum under discussion.

Not only the main texts in the Turkish textbook were structured as to support creative thinking but also the ones in the activities section consist of building blocks that will develop the imagination. It is one of the findings of the study that many activities related to imagination education took place in textbook activities, even though they did not show an equal distribution in every theme.

As a result, $5^{\text {th }}$ grade Turkish textbook activities provide rich opportunities for students to support their creativity, open doors for them to dream, and enrich students' imagination. In terms of both curriculum and textbook activities, research findings show that imagination education can be done effectively with activities.

As a result of this study, some of the objectives related to the skill areas of Turkish curriculum can be performed with the aim of bringing opportunities for developing imagination to the students in the context of creative thinking 
skills. It was seen that some of the activities in the content of the Turkish textbook organization chart, which was examined, were also aimed at this purpose. Nevertheless, the lack of stimuli to support the imagination regarding the cost and printing conditions of the book was also identified through this study.

It was found as result of the study that some of the sections as preparation, listening, reading, speaking, writing, preparation for the next section and theme evaluation questions related to the activities were also at a level that would contribute to imagination education and development of it.

Therefore, suggestions for improving the imagination of students in Turkish teaching courses are as follows:

- It is clear that there is a linear situation between thinking versatile and vocabulary. For this reason, it is recommended to give more place to the studies to improve students' vocabulary both in the curriculum and in Turkish teaching textbook.

- It is thought that in order to support the elements and findings of this study related to imagination in the Turkish lessons, textbook and program, it is important to create an environment that would create new grounds for the formation of new ideas and an atmosphere that increases the imagination in students by teachers.

\section{Kaynakça / References}

Açıkalın, A. (2002). İnsan kaynağının yönetimi geliştirilmesi. Ankara: PegemA. Akkoyun, F. (1993). Saygı kavramına transaksiyonel analiz (TA) açısından bakış. Psikolojik Danışma ve Rehberlik Dergisi, 1 (4), 16-22.

Arık, A. (1990). Yaratıcllk. Ankara: Kültür Bakanlığı Kültür Eserleri Dizisi, 88.

Aslan, E. (2001). Kavram boyutunda yaratıcllık. Türk Psikolojik Danışma ve Rehberlik Dergisi, 16 (2), 15-22.

Davaslıgil, Ü. (1994). Yüksek gizli güce sahip lise öğrencilerinin yaratıcılıkları üzerine bir deneysel araştırma. Atatürk Eğitim Fakültesi Eğitim Bilimleri Dergisi, 6, 53-68.

Demir, T (2012). Türkçe öğretiminde yaratıcı yazma becerisini geliştirme ve küçürek öykü. Mustafa Kemal Üniversitesi, Sos. Bil. Enst. Dergisi, 9, 343-357.

Demirel, Ö. (2009). Eğitimde program geliştirme. Ankara: PegemA. 
Dikici, A. (2001). Sanat eğitiminde yaratıcılık. Milli Ĕ̆itim Dergisi, 149.

Doğan, N. (2015). Yaratıcı düşünme ve yaratıcılık. (Ö. Demirel Ed.), Eğitimde Yeni Yönelimler içinde (s.167-198). Ankara: PegemA.

Dolmaz, M. ve Kaya, E. (2017). Sosyal bilgiler dersinde bir yaratıcı yazma çalışması: yaratıcı yazma becerilerinin çeşitli değişkenler bağlamında incelenmesi. International Journal of Field Education, 3 (2), 1-17.

Haykır Ağın, H., Kaplan, H., Kıryar, A., Tarakçı, R. ve Üstün, E. (2018). Ortaokul ve Imam Hatip Ortaokulu 5. Sınıf Türkçe ders kitabı, Ankara: Devlet Kitaplar1, Özgün.

Kırışoğlu, O. (1991). Sanatta eğitim : Görmek, anlamak, yaratmak. Ankara: Eğitim. MEB Komisyon (2018).Türkçe dersi öğretim programı: 1-8. Ankara.

Miles, M. B ve Huberman A. M. (1994). An expanded sourcebook: Qualitative data analysis. CA: Sage.

Oğuzkan, Ş, Özgür, D. ve Tür, G. (1999). Okul öncesinde yaratıcı çocuk etkinlikleri. İstanbul: Ya-Pa.

Rıza, E. T. (2000). Çocuklarda ve yetişkinlerde yaratıcılık nasıl uyarılır? Yaşadikça Ĕ̆itim Dergisi. Ekim/Aralık, 68, 5-12.

Samurçay, N. (1983). Zekâ ve yaratıcılık. Eğitim ve Bilim, 8(45), 4-12.

San, İ. (1979). Sanatsal yaratma, çocukta yaratıcılık. Ankara: Türkiye İş Bankası Kültür.

San, İ. (1985). Sanat ve eğitim. Ankara Üniversitesi Eğitim Bilimleri Fakültesi, No: 151, Ankara: Ankara Üniversitesi.

Tavşancıl, E. ve Aslan, E. (2001). İçerik analizi ve uygulama örnekleri. Epsilon Yayınlar1

TDK (2011). Büyük Türkçe sözlük. Ankara: Türk Dil Kurumu.

Temizkan, M. (2011). Türkçe öğretiminde yaratıcı düşünmeyi geliştirme bakımindan nasreddin hoca fikraları. Mustafa Kemal Üniversitesi, Sos. Bil. Enst. Dergisi, 8 (16), 195-223.

Thomas, D. ve Brown, J. S (2016). Yeni nesil öğrenme kültürü, sürekli değişen bir dünya için hayal gücü yetiştirmek. (H. Uysal Çev. Ed.). Ankara: Pegem Akademi.

Ülgen, G. (1997). Ĕgitim psikolojisi. Ankara: Alkım.

Ünveren Kapanadze, D. (2018a). Toplumsal bellek bağlamında kültür, dil ve öğretimi. (O. Kutlu Ed.). Eğitim Bilimleri içinde (s.299-322). Ankara: Akademisyen. 
Ünveren Kapanadze, D. (2018b). Dil ve kültür aktarımında işlevsel bir araç olarak ders kitapları: Türkçe ders kitapları örneği. Turkish Studies, 13 (27), 1575-1592.

Üstündağ, T. (2014). Yaratıcllığa yolculuk. Ankara: PegemA.

Wilson, L. O (1997). ‘Creativity is...' http//www.uwsp.edu/Education/Wilson/index.html adresinden erişilmiştir.

Yıldırım, A. ve Şimşek, H. (2013). Sosyal bilimlerde nitel araştırma yöntemleri. Ankara: Seçkin

\section{Kaynakça Bilgisi / Citation Information}

Ünveren, D. (2020). Türkçe öğretiminde hayal gücü ve yaratıcllı eğitimi. OPUS-Uluslararası Toplum Araştırmaları Dergisi, 15(21), 378-404. DOI: 10.26466/opus.656984 